\title{
Motivation in the use of digital platforms for teaching and learning mathematics
}

\author{
David Méndez Coca, Miriam Méndez Coca, Juana Ma Anguita Acero, Carolina Suárez \\ Llevat
}

Alfonso X El Sabio University, SPAIN

\begin{abstract}
.
The integration of ICT in education and their use in effective didactic practices are favored when teachers' motivation increases. The Theory of Self-Determination (Deci and Ryan, 2000) focuses on the study of intrinsic motivation and on the types of extrinsic motivation that can be internalized in order to motivate an individual's behavior. Research has been carried out with $2^{\text {nd }}$ and $3^{\text {rd }}$ year students of the university Primary Education Degree program, analyzing the factors that favor their intrinsic motivation after carrying out activities using digital platforms for teaching and learning mathematics. The factors assessed were: the subject's satisfaction with or interest in the use of the digital platforms, his/her perception of the competence he/she had and the value or utility provided by the activity. The intrinsic motivation in both groups was high, and was higher in students that did not have previous experience with digital platforms than in students that had previous experience.
\end{abstract}

Keywords: e-learning, experience, initial teacher training, intrinsic motivation, Theory of SelfDetermination

\section{Introduction}

Since the appearance of technologies, they have rapidly evolved and their presence has spread throughout society. In consequence, there is a growing interest in incorporating them into education as an objective, as teaching and learning content, and also as a teaching and methodological resource. Several research studies have documented the growing presence of ITCs in different syllabuses (Means and Olson, 1995; Means, Penuel and Padilla, 2001; Sandholtz, Ringstaff and Dwyer, 1997; Schofield and Davidson, 2002; Voogt and Pelgrum, 2005; UNESCO, 2012; Voogt and Roblin, 2013; Kozma, 2003, 2005).

Necessary organizational changes have been made in schools and in classrooms for the integration of information and communication technologies. However, these have not been accompanies by technological and pedagogical innovation (Coll, 2008; Area, 2008; Area, 2010; Sutherland, 2004; Balanskat, Blamire and Kefala, 2006; Becta, 2013). At present, the barriers to the integration of technologies in the classroom identified by teachers are the following: lack of training and knowledge regarding ICT, lack of technical support in the use of said technologies (Keong, Horani and Daniel, 2005), lack of confidence, lack of competence, lack of resources (Nikolopoulou, Gialamas, 2013; Bingimlas, 2009) and the excess workload or lack of time to integrate them (Sang, Valcke, van Braak, Tondeur and Zhu 2011; Keengwe, 
Onchwari and Wachira, 2008). Mauri and Onrubia, (2008) recommend that for the use of virtual surroundings in education, a necessary but insufficient requirement is that teachers must positively value the results they can achieve with the integration of ICT's in education, and must know and value the technological tools that can be used in the classroom.

The integration of ICTs in the classroom frequently entails a change in the usual teaching practices, with teachers assuming a certain degree of insecurity and having to look for solutions to the errors that new knowledge can provoke. Sutherland and his collaborators (2004) classify the different practices with technologies that are developed in the classroom: some are a prolongation of the teaching and learning outlines of books; others try to achieve a balance between individualized learning proposed as individualized learning environments and group learning-teaching in the classroom. Drijvers (2013) highlights three uses of ICTs in math classes: a) ICTs as tools to do mathematics; b) the use of applications as a learning environment for the development of skills; c) the use of applications as a learning environment to work on the comprehension of concepts. Goos (2010) explains that mathematical knowledge is a process of construction starting with the development of the mathematical activity performed by the students, through interaction with mathematical ideas, through the relationship with other students or teachers in mathematics learning-teaching experiences or in the interaction in a context, problem situation that can be caused by the technology. Sarama and Clements (2009), Moyer, Niezgoda and Stanley (2005) analyze and document that use of ICT can provide students with a virtual representation of mathematical concepts and procedures that favor learning, similar to the one produced by the manipulation of didactic materials. Uttal, O’Doherty, Newland and Hand (2009) recommend using virtual representations and at the same time symbolic representations of mathematical objects to support the flexibility of use of mental representations that favor mathematical learning.

\section{The Theory of Self-Determination}

The different theories of motivation are considered important in the field of education because of their applications. The Theory of Self-Determination is one of sad theories which enjoys considerable empirical support centered on intrinsic motivation (Pintrich \& Schunk, 2006).

The Theory of Self-Determination (Ryan \& Deci, 2000; Deci \& Ryan, 1985) is a theory that describes human motivation and the factors that facilitate or prevent motivation. Individuals have three basic psychological needs: the need to perceive one's own competence, the need for autonomy and freedom, and the need to interact. When one or all of these needs are satisfied, there is an increase of motivation, and when they are not, motivation decreases. The Theory of Self- Determination describes and analyses the results obtained in its application in education, sports, work, etc.

Deci and Ryan (1985) recognize intrinsic motivation as something innate to human beings and associate it to conduct that seeks one's owner satisfaction, without external or personal pressure and without any instrumental intentionality. This motivation is linked to conducts of exploration, motivated by curiosity or by a playful interest. Deci and Ryan (1985) study the environmental and social factors that can favor or dissuade this motivation. Activities, practices 
and tasks freely chosen by the individual that are perceived as challenges, as interesting or fun and that promote the perception of one's own competence favor intrinsic motivation. But some external factors can also help to improve this intrinsic motivation, such as messages of positive reinforcement. On the contrary, negative messages or even tangible rewards worsen this motivation. For intrinsic motivation to exist, there must a perception of autonomy; in other words, that individual must feel that he/she freely chooses the task or the practices. When pressure or external control is perceived, intrinsic motivation diminishes. Teachers who Support autonomy, who propose to their students challenging activities or practices, and who reinforce their students with positive messages improve the motivation of their students. On the contrary, students who are more controlling not only reduced their students' initiative, but also diminish the effective learning, in particular of conceptual content and the development of creative strategies (Amabile, 1996 and Utman, 1997).

Deci and Ryan $(2000,1985)$ describe a variety of intrinsic motivations as a continuum that goes from an unmotivated conduct to the motivation that enables a student to choose and commit to a conduct or practice. This variability of external motivation towards an activity or practice is caused by the type of regulation of the former: external to the individual or interiorized in different degrees. This interiorization of motivation may occur in conduct caused to avoid guilt, anxiety or to show to the individual his/her capacity, and its worth is called introjected regulation. The regulation of motivation is considered to be more assimilated when the activity and/or the practice are valued as important for the individual and receives the name of regulation through integration. Thus, motivation that results from achievement objectives depending on whether the type of extrinsic motivation is perceived as more externally or internally interiorized affects the level of effort, responsibility, interest and enjoyment. Factors that affect this internalization of extrinsic motivation may be need for competence, to interact and the perception of freedom one has to choose.

\section{Digital e-learnig platforms for mathematical education}

Wagner (2005) defined e-learning as the educational process that uses information and communication technologies to provide learning distribute contents, favour communication between students and teachers and manage the different aspect of the learning and teaching process. E-learning enables students to learn at their own speed, facilitating their autonomy. It tends to be interactive; it is independent of the time and space in which the teacher and student find themselves, enabling flexible and accessible learning. (Duhaney \& Duhaney, 2000; Cabero, et al., 2005, 2006; Baya'a \& Daher, 2012).

Through e-learning teachers seek to improve the cognitive and motivating results for learning and to develop skills and strategies to improve learning processes. E-learning has grown, in particular, in formal and non-forma higher education.

Rovai et al. (2007) found that the intrinsic motivation of students taught with e-learning was greater than that of students taught in a traditional manner. Wan, Wang and Haggerty (2008) conclude that experiences with ICTs and one's virtual competence are two factors that have a positive influence in the use of e-leaning. In a research study involving 2196 students and 29 universities in Austria, Paechter, Maier and Macher (2010) detected two important factors for 
the success of e-learning: students' assessment of the achievements they can reach as well as the experience and support of the instructor or teacher.

Valentín et al. (2013) carried out a study of the use of ICTs and the factors that had an influence on their use with a simple of 534 university students. They obtained a significant coefficient, but of low intensity that linked the expectations of use of ICTs with an improvement of results and satisfaction in study programs that use the educational platforms.

\section{Methodology}

The objective of the research is to know the motivation of future elementary school teachers for the use of ICTs in their math classes in the future. For this purpose, during one month they practiced using digital platforms, namely Khan Academy, Matific, IXL and Smartick in two courses of didactics for mathematics, in the degree program for 1st, 2nd and 3rd grade teachers. In particular they focused on the use of platforms for learning and teaching mathematics in elementary school performing the activities proposed, reviewing the corrections made by the platforms, the positive reinforcement messages and the motivating elements they contain, the type of exercises they propose, the representations used, imagining how they could use them in the future as teachers. One session was held in the classroom to familiarize themselves with the platforms and to interact. Afterwards they performed, in groups of three and four student, a practical exercise to analyze the platforms. Later, In January 2019 they were given a questionnaire to measure three dimensions of motivation: the interest and satisfaction with which they engaged in the practical exercise, the mode in which they perceive their competence in the use of these tools, and the value they attach to the use of these platforms.

The simple consisted of two groups of students in the Elementary Education Degree Program at a public university in Madrid: one group of second year students and a group of third year students. The sample of the second year students consisted of 43 students, of which 22 had previously used the platforms and 21 who had not. The sample of the group of third year students consisted of 26 persons, 11 of which had previously sued the platforms and 15 who had not. All of them had laptops. In the third year-student group, the average number of hours they used the computer per week was 12 , whereas for the second year group the average sued of the computer was 8 hours per week.

\subsection{Instrument}

The instrument is an IMI questionnaire comprising 20 Likert scale questions with 7 levels of grading of the answers: 7 questions ( 2 reverted) to assess the dimension of student interest and satisfaction in performing the task of using the platforms for teaching and learning mathematics; 6 questions ( 1 reverted) to assess how competent students feel for this task; and a third dimension assessed with 7 questions to evaluated the utility and importance they attach to the task. Grading went from 1 Completely disagree to 7 Completely agree.

\subsection{Results}

The results of the questions of each dimension are shown below: 
Table 1: Average of the answers of the second and third year students of the Elementary Teacher Degree program to questions regarding their interest and satisfaction in respect to the use of digital platforms for teaching and learning mathematics

\begin{tabular}{|c|c|c|c|c|}
\hline \multirow[b]{2}{*}{ ITEMS } & \multicolumn{2}{|c|}{ Second year Elementary } & \multicolumn{2}{|c|}{ Third year Elementary } \\
\hline & Used platf & $\begin{array}{l}\text { Did not use } \\
\text { platf }\end{array}$ & Used platf & $\begin{array}{l}\text { Did not use } \\
\text { platf }\end{array}$ \\
\hline $\begin{array}{l}\text { 1) The task of using digital platforms } \\
\text { to learn mathematics was fun. }\end{array}$ & $5.64 \pm 1.07$ & $6.14 \pm 0.65$ & $5.64 \pm 0,88$ & $6.00 \pm 0.82$ \\
\hline $\begin{array}{l}\text { 2) During the time devoted to the } \\
\text { task of using digital platforms to } \\
\text { learn mathematics, I realized that I } \\
\text { was having a great time. }\end{array}$ & $5.55 \pm 1.20$ & $5.86 \pm 1,01$ & $5.36 \pm 0.64$ & $5.67 \pm 1.19$ \\
\hline $\begin{array}{l}\text { 3) I thought that using digital } \\
\text { platforms to learn mathematics was } \\
\text { a boring activity. (R) }\end{array}$ & $4.50 \pm 1.59$ & $4.38 \pm 1.68$ & $4.45 \pm 1.67$ & $5.27 \pm 0.68$ \\
\hline $\begin{array}{l}\text { 4) When I performed the task of } \\
\text { using digital platforms to learn } \\
\text { mathematics, I thought it was rather } \\
\text { fun. }\end{array}$ & $5.41 \pm 1.11$ & $5.90 \pm 0.70$ & $5.73 \pm 0.86$ & $5.60 \pm 1.14$ \\
\hline $\begin{array}{l}\text { 5) I did not like using digital } \\
\text { platforms to learn mathematics. }(\mathrm{R})\end{array}$ & $5.45 \pm 0.89$ & $5.67 \pm 0.71$ & $5.45 \pm 0.66$ & $5.73 \pm 0.44$ \\
\hline $\begin{array}{l}\text { 6) I greatly enjoyed performing the } \\
\text { activity of using digital platforms to } \\
\text { learn mathematics. }\end{array}$ & $5.41 \pm 1.27$ & $5.81 \pm 0.87$ & $5.91 \pm 0.90$ & $5.47 \pm 1.50$ \\
\hline $\begin{array}{l}\text { 7) I would describe the activity of } \\
\text { using digital platforms to learn } \\
\text { mathematics as very interesting. }\end{array}$ & $5.45 \pm 1.20$ & $6.14 \pm 0.73$ & $5.91 \pm 0.79$ & $5.87 \pm 1.20$ \\
\hline
\end{tabular}

A higher average was obtained for each item by the second year students of the Elementary School Teacher Degree who had not previously used digital platforms than by the ones who had used them, except for question 3. Observing the deviations, we note that that here is less dispersion amongst the students who had not used platforms than amongst those who had. The two subgroups of second year students gave the highest grade to item 1, and the lowest to item 3. In this dimension the average of the students who had not used platforms is 5.70 and the average of the students who had used platforms is 5.34.

The sample of third year students of the Elementary School Teacher Degree program who had not previously used platforms gave the highest grade to ítem1 (regarding whether the task of using the platforms is a fun activity) and then to item 7, which asked if they had found using the platforms interesting, like what happened to the second year students. They also coincide with the sample of second year students in giving a lower value to item 3 . The highest grade in the group of students who had not used the platforms was for items 6 and 7. The average of this dimension for students how had not used platforms is 5.66, and 5.49 in the subgroup of students who had used platforms. 
The second year students of the Elementary School Teacher Degree program who had used platforms valued this dimension with a lower grade than the other dimensions. In this dimension, the sample of third year students obtains an average of 5.58, slightly higher than the one obtained by the second year students, which is 5.52.

A higher average was obtained for each item by the second year students of the Elementary School Teacher Degree who had not previously used digital platforms than by the ones who had used them, except for question 3. Observing the deviations, we note that that here is less dispersion amongst the students who had not used platforms than amongst those who had. The two subgroups of second year students gave the highest grade to item 1, and the lowest to item 3. In this dimension the average of the students who had not used platforms is 5.70 and the average of the students who had used platforms is 5.34.

Table 2: Average of the answers of the second and third year students of the Elementary Teacher Degree program to questions regarding how they perceive their competence in the use of digital platforms as a resources for teaching and learning mathematics.

\begin{tabular}{|l|l|l|l|l|}
\hline \multirow{2}{*}{ ITEM } & \multicolumn{1}{|c|}{ Second year Elementary } & \multicolumn{2}{c|}{ Third year Elementary } \\
\cline { 2 - 5 } & Used platf & $\begin{array}{l}\text { Did not use } \\
\text { platf }\end{array}$ & Used platf & $\begin{array}{l}\text { Did } \\
\text { platf }\end{array}$ \\
\hline $\begin{array}{l}\text { 8) After using digital platforms to } \\
\text { learn mathematics, I felt that I was } \\
\text { good at using them. }\end{array}$ & $5.59 \pm 0.94$ & $5.95 \pm 1.02$ & $6.09 \pm 0.67$ & $5.80 \pm 1.05$ \\
\hline $\begin{array}{l}\text { 9) I did quite well using digital } \\
\text { platforms to learn mathematics. }\end{array}$ & $5.91 \pm 0.79$ & $5.95 \pm 1.00$ & $5.82 \pm 0.72$ & $5.87 \pm 1.09$ \\
\hline $\begin{array}{l}\text { 10) I think that I am quite good at } \\
\text { using digital platforms to learn } \\
\text { mathematics in comparison with } \\
\text { other classmates. }\end{array}$ & $4.50 \pm 1.16$ & $4.86 \pm 1.09$ & $4.55 \pm 1.37$ & $4.13 \pm 1.36$ \\
\hline $\begin{array}{l}\text { 11) I was not very good in the activity } \\
\text { of using digital platforms able to learn } \\
\text { mathematics. (R) }\end{array}$ & $5.41 \pm 0.65$ & $5.19 \pm 1.25$ & $5.09 \pm 0.67$ & $5.47 \pm 1.02$ \\
\hline $\begin{array}{l}\text { 12) I am satisfied with my } \\
\text { performance in the task of using } \\
\text { digital platforms to learn } \\
\text { mathematics. }\end{array}$ & $5.95 \pm 0.88$ & $6.05 \pm 0.80$ & $5.82 \pm 0.72$ & $5.93 \pm 0.68$ \\
\hline $\begin{array}{l}\text { 13) I think I am quite good in using } \\
\text { digital platforms to learn } \\
\text { mathematics. }\end{array}$ & $5.18 \pm 1.23$ & $5.57 \pm 0.97$ & $5.45 \pm 0.99$ & $5.27 \pm 1.00$ \\
\hline
\end{tabular}

Once again, the valuation of all items is more positive in the group of second year students that did not use the platforms than in the group that had used them, except for item 11 . The average of the students who did not use platforms is 5.64, and 5.41 for the second year students who had previously used platforms. Item 12, namely satisfaction with their own performances, is the one that both subgroups of second and third year students valued most. In contrast, item 
10 is the one that both subgroups valued less; in other words, they did not value it more than their classmates in second and third studies.

The average of the second year students who used platforms is 5.41, and 5.47 in the subgroup that had not previously used platforms. However, the subgroup that had previously used platforms valued item 8, which assesses student confidence in the use of platforms after having used them, better in their third year. The average obtained in the second year sample is 5.53 and 5.44 in the third year, with a slight change of the trend obtained in the first dimension.

Table 3: Average of the answers of the second and third year students of the Elementary Teacher Degree program to questions regarding the value they assign to the use of digital platforms.

\begin{tabular}{|c|c|c|c|c|}
\hline \multirow[b]{2}{*}{ ITEMS } & \multicolumn{2}{|c|}{ Second year Elementary } & \multicolumn{2}{|c|}{ Third year Elementary } \\
\hline & Used platf & $\begin{array}{l}\text { Did not use } \\
\text { platf }\end{array}$ & Used platf & $\begin{array}{l}\text { Did not use } \\
\text { platf }\end{array}$ \\
\hline $\begin{array}{l}\text { 14) I think that knowing about } \\
\text { digital platforms to learn } \\
\text { mathematics would help me be a } \\
\text { good teacher in the future. }\end{array}$ & $6.14 \pm 0.81$ & $6.57 \pm 0.74$ & $6.36 \pm 0.64$ & $6.73 \pm 0.44$ \\
\hline $\begin{array}{l}\text { 15) I think that performing the } \\
\text { activity of using digital platforms to } \\
\text { learn mathematics is useful for a } \\
\text { teacher's future professional career. }\end{array}$ & $6.14 \pm 0.76$ & $6.29 \pm 0.77$ & $6.27 \pm 0.66$ & $6.53 \pm 0.72$ \\
\hline $\begin{array}{l}\text { 16) I could use digital platforms } \\
\text { again to learn mathematics because } \\
\text { I found it interesting. }\end{array}$ & $5.45 \pm 1.30$ & $6.05 \pm 0.86$ & $5.82 \pm 0.57$ & $5.60 \pm 0.88$ \\
\hline $\begin{array}{l}\text { 17) I think that the activity of using } \\
\text { digital platforms to learn } \\
\text { mathematics is important for my } \\
\text { future. }\end{array}$ & $5.86 \pm 1.01$ & $6.00 \pm 0.86$ & $6.00 \pm 0.74$ & $6.27 \pm 0.93$ \\
\hline $\begin{array}{l}\text { 18) I think that using digital } \\
\text { platforms to learn mathematics is an } \\
\text { important activity. }\end{array}$ & $5.77 \pm 1.08$ & $6.24 \pm 0.60$ & $5.82 \pm 0.72$ & $6.33 \pm 0.79$ \\
\hline $\begin{array}{l}\text { 19) I think that using digital } \\
\text { platforms to learn mathematics is } \\
\text { beneficial for me. }\end{array}$ & $5.59 \pm 1.15$ & $6.29 \pm 0.70$ & $6.00 \pm 0.85$ & $6.33 \pm 1.01$ \\
\hline $\begin{array}{l}\text { 20) I think that the activity of using } \\
\text { digital platforms to learn } \\
\text { mathematics could be valuable for } \\
\text { me. }\end{array}$ & $5.68 \pm 1.22$ & $6.19 \pm 0.65$ & $6.18 \pm 0.83$ & $6.27 \pm 1.29$ \\
\hline
\end{tabular}

The average of the dimension amongst second year students who had used platforms is 5.81 and the average of the second year students who had not used platforms is 6.23. In both groups this is dimension that obtained the highest valuation. In addition, we see that the dispersion in the group of student that had not used the platforms is less than in the group that had used them previously. The valuation for all questions was greater than 6 in the group of second year students that had not used the platforms. The item that was most valued by both second and 
third year students, in this dimension and all the others, is item 14, namely the importance they attribute to knowing about digital platforms for their future.

In the group of third year students of the Elementary Teacher Degree program the averages are greater than in the second year students. The average obtained among students who had used platforms was 6.06, and 6.30 in the group that had not used them. For second year students, the average of the group that had used platforms was 5.81, and 6.23 amongst the group that had not used them. This dimension is also the one that was valued best by students. The average obtained for third year students is 6.18, and 6.02 for second year students. One again, a higher value is obtained by third year students than by second year students.

On analyzing whether there were significant differences between the group of second year students who had previous experience with platforms and the group that did not have previous experience, significant differences were found $(\mathrm{p}=0.038)$ using the student's t-test with 18 degrees of freedom. However, no significant differences were found between the groups of third year students.

\subsection{Discussion}

The results are very positive in for both second and third year students. There are differences of intrinsic motivation between the averages of students who had used platforms to learn mathematics and the ones who had not used them previously, with a greater valuation of nearly all item by students that had not used platforms previously. Moreover, in the dimensions to assess their competence in the use of platforms, o to assess platforms as fun, the values were slightly lower than the ones obtained in students' valuation of the importance of knowing about platforms.

The results confirm those of a previous study performed with 957 elementary school teachers by Leung, Watters and Ginns (2005), which shows that the perception of one's skills and knowledge is more valued by persons who have less experience than by persons with more experience.

In a research study with 140 fourth year students of the Elementary Teacher Degree program in an experience to learn Chinese with games, it was noted that the intrinsic motivation and prior knowledge of Chinese had an influence in the results achieved by students (Baek et al., 2015). Furthermore, both aspects, that is intrinsic motivation and prior knowledge of Chinese, affected each other. In this experience, the mathematical knowledge that mobilized the students in the platforms was at the elementary level, which might also have influenced the motivation reached.

Although prior experience may be a factor that affects motivation in the use of ICTs, there continue to be research studies with contradictory results. For example Albirini (2006) studied the attitudes of 320 English teachers in Syria towards ICTs and the factors that conditioned their use. These attitudes were the perception of competence for the use of ICTs and their valuation of ICTs, irrespective of the experience they had in using them.

In a study of 1071 elementary science teachers in Turkey. Cavas, et al. (2009) showed that there were no significant differences between attitudes towards the use of ICTs and gender. 
However, their results revealed differences considering prior experience with computers, although they were the opposite of the results obtain in this research study.

\section{Conclusion}

There are numerous studies on the valuation of ICTs by teachers. However, this recognition is not followed by their integration in the classroom because teachers demand more knowledge of teaching practices with technology and more confidence in the use of technological resources.

Teacher training and motivation of teachers and future teachers for the integration of technologies in the classroom with pedagogical and didactic criteria is essential. This study shows how the use of activities with technologies in classrooms of elementary school teacher degree program students can entail greater motivation for future teachers who do not have previous experience than for those that have had previous experience. Both subgroups, however, value and consider that use of new technologies in the classroom nowadays is important.

\subsection{References}

[1] Albirini, A. (2006). Teachers' attitudes toward information and communication technologies: the case of Syrian EFL teachers, Computers \& Education, vol. 47, pp. 373398.

[2] Amabile, T. M. (1996). Creativity in context: update to the social psychology of creativity. Boulder, CO: West view Press.

[3] Area, M. (2010). El proceso de integración y uso pedagógico de las TIC en los centros educativos. Un estudio de casos. Revista de educación, 352, pp. 77-97.

[4] Area. M. (2008). La innovación pedagógica con TIC y el desarrollo de las competencias informacionales y digitales. Investigación en la escuela, 64, pp. 5-17.

[5] Baek, X. and Han, C. (2015). Exploring Effects of Intrinsic Motivation and Prior Knowledge on Student Achievements in Game-based Learning. Smart Computing Review, 5(5), pp. 368-377.

[6] Balanskat, A., Blamire, R. and Kefala, S. (2006). The ICT impact report. A review of studies of ICT impact on schools in Europe. European Schoolnet, European Commission. Retrieved from http://insight.eun.org/shared/data/pdf/impact_study.pdf

[7] Baya'a, N. and Daher, W. (2012). From Social Communication to Mathematical Discourse in Social Networking: The Case of Facebook. International Journal of Cyber Ethics in Education, 2(1), pp. 58-67.

[8] Bingimlas, K. A. (2009). Barriers to the successful integration of ICT in teaching and learning environments: a review of the literature. Eurasia Journal of Mathematics, Science and technology education, 5(3), pp. 235-245.

[9] Cabero, J. (2006). Bases pedagógicas del e-learning. Revista de la Universidad y Sociedad del Conocimiento, 3(1), pp. 1-10. 
[10] Cabero, J. and Gisbert, M. (2005). Formación en Internet. Guía para el diseño de materiales didácticos. Sevilla: MAD.

[11] Cavas, B., Cavas, P., Karaoglan, B. and Kisla, T. (2009). A study on science teachers' attitudes toward information and communication technologies in education. The Turkish Online Journal of Educational Technology, 8(2), pp. 20-32.

[12] Coll, C. (2008). Aprender y enseñar con las TIC. Expectativas, realidad y potencialidades. Boletín de la Institución Libre de Enseñanza, 72, pp. 17-40.

[13] Deci, E. L. and Ryan, R. M. (1985). Intrinsic motivation and self-determination in human behavior. New York, NY: Plenum.

[14] Deci, E. L. and Ryan, R. M. (2000). The "what" and "why" of goal pursuits: Human needs and the self-determination of behavior. Psychological Inquiry, 11, pp. 227-268.

[15] Drijvers, P. (2013). Digital technology in mathematics education: why it works (or doesn't).PNA, 8(1), pp. 1-20.

[16] Duhaney, D. C. and Duhaney, L. M. G. (2000). Assistive Technology: Meeting the needs of Learners with Disabilities. International Journal of Instructional Media, 27(4), pp. 393-401.

[17] Goos, M. (2010). Using technology to support effective mathematics teaching and learning: what counts? Research Conference on Teaching Mathematics? Makes It Count: What researcht tells us about effective teaching and learning of mathematics. Retrieved from

http://research.acer.edu.au/cgi/viewcontent.cgi?article=1067\&context=research_conferenc e

[18] Keengwe, J., Onchwari, G. and Wachira, P. (2008). Computer Technology Integration and Student Learning: Barriers and Promise. Journal of Science Education and Technology, 17(6), pp. 560-565.

[19] Keong, C.C., Horani, S. and Daniel, J. (2005). A study on the use of ICT in mathematics teaching. Malaysian Online Journal of Instructional Technology (MOJIT),3(2), pp. 43-51.

[20] Kozma, R. B. (2005). National Policies that Connect ICT-Based Education Reform to Economic and Social Development. Human Technology, 1 (2), pp. 117-156.

[21] Kozma, R.B. (2003). Technology and Classroom Practices: An International Study. Journal of Research on Technology in Education, 36 (1), pp. 1-14.

[22] Leung, K.P., Watters, J.J. and Ginns, I.S. (2005). Enhancing Teachers' Incorporation of ICT in Classroom Teaching. In Proceedings 9th Annual Global Chinese Conference on Computes in Education. Brigham Young University, Hawaii, USA.

[23] Mauri, T., and Onrubia, J. (2008). El profesor en entornos virtuales: Condiciones, perfil y competencias. In C. Coll and C. Monereo (Eds.), Psicología de la educación virtual (pp.132-152). Madrid: Ediciones Morata S.L.

[24] Means, B., Penuel, W. and Padilla, C. (2001). The connected school: Technology and learning in high school. San Francisco: Jossey-Bass. 
[25] Means, B. and Olson, K. (1995). Technology's role in education reform: Findings from a national study of innovating schools. Washington, DC: U.S. Department of Education, Office of Educational Research and Improvement.

[26] Moreno, J. A. and Martínez, A. (2006). Importancia de la Teoría de la Autodeterminación en la práctica físico-deportiva: Fundamentos e implicaciones prácticas. Cuadernos de Psicología del Deporte, 6(2), pp. 39-54.

[27] Moyer, P. S., Niezgoda, D. and Stanley, J. (2005). Young children's use of virtual manipulatives and other forms of mathematical representations. In W. J. Masalski and P. C. Elliott (Eds.), Technology-supported mathematics learning environments (pp. 17-34). Reston, VA: NCTM.

[28] Niederhauser, D. S. and Stoddart, T. (2001). Teachers' instructional perspectives and use of educational software. Teaching and Teacher Education: An International Journal of Research and Studies, 17(1), pp. 15-31.

[29] Nikolopoulou, K. and Gialamas, V. (2013). ICT and play in preschool: early childhood teachers' beliefs and confidence. International Journal of Early Years Education, 23(4), pp. $1-17$.

[30] Paechter, M., Maier, B. and Macher, D. (2010) Students' Expectations of and Experiences in E-Learning: Their Relation to Learning Achievements and Course Satisfaction. Computers \& Education, 54, pp. 222-229.

[31] Pintrich, P. R. and Schunk, D.H. (2006). Motivación en contextos educativos. Madrid, Pearson.

[32] Rovai, A. P., Ponton, M. K., Wighting, M. J. and Baker, J. D. (2007). A comparative analysis of student motivation in traditional classroom and e-learning courses. International Journal on E-Learning, 6, pp. 413- 432.

[33] Ryan, R. M. and Deci, E. L. (2000). Self-determination theory and the facilitation of intrinsic motivation, social development, and well-being. American Psychologist, 55, pp. 68-78.

[34] Sandholtz, J., Ringstaff, C. and Dwyer, D. (1997). Teaching with technology: Creating student-centered classrooms. New York: Teachers College Press.

[35] Sang, G., Valcke, M., van Braak, J. and Tondeur, J. (2010). Student teachers' thinking processes and ICT integration: Predictors of prospective teaching behaviors with educational technology. Computers \& Education, 54, pp. 103-112.

[36] Sandholtz, H., Ringstaff, K. and Dwyer, D. (1997). Teaching with Technology: Creating student centered classrooms. New York: Teachers' College Press.

[37] Sarama, J. and Clements, D. H. (2009). "Concrete"' Computer Manipulatives in Mathematics Education. Child Development Perspectives, 3(3), pp. 145-150.

[38] Schofield, J. and Davidson, A. (2002). Bringing the Internet to school: Lessons from an urban district. San Francisco: Jossey-Bass. 
[39] Sutherland, R., Armstrong, V., Barnes, S. (2004). Transforming teaching and learning: embedding ICT into everyday classroom practices. Journal of Computer Assisted Learning, 20 (6), pp. 413-425.

[40] United Nations Educational, Scientific and Cultural Organization [UNESCO]. (2012). ICTs for curriculum change. Retrieved from https://unesdoc.unesco.org/ark:/48223/pf0000220243

[41] Utman, C. H. (1997). Performance Effects of Motivational State: A Meta-analysis. Personality and Social Psycholgy Review, 1(2), pp. 170-182.

[42] Uttal, D. H.; O’Doherty, K.; Newland, R., Hand,L. L. and DeLoache, L. (2009). Dual Representation and the Linking of Concrete and Symbolic Representations. Child Development Perspectives, 3(3), pp. 156-159.

[43] Valentín, A., Mateos, P. M., González-Tablas, M. M., Pérez, L., López, E. and García, I. (2013). Motivation and learning strategies in the use of ICTs among university students. Computers \& Education, 61, pp. 52-58.

[44] Voogt, J. and Pelgrum, H. (2005). ICT and Curriculum Change. Human Technology, an Interdisciplinary Journal on Humans in ICT Environments, 1 (2): pp. 157-175.

[45] Voogt, J. and Roblin, N. P. (2013). A comparative analysis of international frameworks for 21st century competences: Implications for national curriculum policies, Journal of Curriculum Studies, 44(3).pp. 299-321.

[46] Wagner, E.D. (2005). Enabling Mobile Learning. EDUCAUSE Review, 40(3), pp. 4053.

[47] Wan, Z., Wang, Y. and Haggerty, N. (2008). Why people benefit from e-learning differently: The effects of psychological processes on e-learning outcomes. Information \& Management, 45(8), pp. 513-521. 